\title{
Morphological Transformation of Peptide Nanoassemblies through Conformational Transition of Core-forming Peptides
}

\author{
Tomonori Waku *, Naoyuki Hirata, Masamichi Nozaki, Kanta Nogami, Shigeru Kunugi and \\ Naoki Tanaka \\ Faculty of Molecular Chemistry and Engineering, Kyoto Institute of Technology, Gosyokaido-cho, Matsugasaki, \\ Sakyo-ku, Kyoto 606-8585, Japan; h.naoyuki332@gmail.com (N.H.); m.nozaki.kit@gmail.com (M.N.); \\ kotetuzeroshiki@i.softbank.jp (K.N.); kunugi@snr.kit.ac.jp (S.K.); tanaka@kit.ac.jp (N.T.) \\ * Correspondence: waku1214@kit.ac.jp; Tel.: +81-75-724-7811
}

Received: 31 October 2018; Accepted: 19 December 2018; Published: 28 December 2018

\begin{abstract}
Morphological control of nanostructures that are composed of amphiphilic di- or tri-block molecules by external stimuli broadens their applications for molecular containers, nanoreactors, and controlled release materials. In this study, triblock amphiphiles comprising oligo(ethylene glycol), oligo(L-lysine), and tetra(L-phenylalanine) were prepared for the construction of nanostructures that can transform accompanying $\alpha$-to- $\beta$ transition of core-forming peptides. Circular dichroic (CD) measurements showed that the triblock amphiphiles adopted different secondary structures depending on the solvent environment: they adopt $\beta$-sheet structures in aqueous solution, while $\alpha$-helix structures in 25\% 2,2,2-trifluoroethanol (TFE) solution under basic $\mathrm{pH}$ conditions. Transmission electron microscopic (TEM) observation revealed that the triblock amphiphiles formed vesicle structures in $25 \%$ TFE aq. Solvent exchange from $25 \%$ TFE to water induced morphological transformation from vesicles to arc-shaped nanostructures accompanying $\alpha-\beta$ conformational transition. The transformable nanostructures may be useful as novel smart nanomaterials for molecular containers and micro reactors.
\end{abstract}

Keywords: aromatic peptides; self-assembly; morphological change; secondary structure

\section{Introduction}

Amphiphilic di- or tri- block type molecules with hydrophilic and hydrophobic segments can self-assemble into various core-shell type nanostructures, such as micelles, vesicles, tubes, and fibers [1]. Morphological control of these nanostructures by external stimuli broadens their applications for molecular containers, nanoreactors, and controlled release materials. Therefore, various molecular designs have been reported for the construction of such smart nanomaterials that can respond to changes in the external environment, including $\mathrm{pH}$, temperature, and solvent composition [2-4]. Among these, amphiphilic molecules, consisting of polypeptides, have been widely used as a building block for smart nanomaterials, as they exhibit a transition of secondary structures: $\alpha$-helix, $\beta$-sheet, and random conformations [5-8]. The secondary structure transition of core-forming polypeptides can induce further drastic morphological changes, in contrast to that of shell-forming ones, which usually leads to changes only in the diameter of the nanostructures [9-13]. To date, many studies on the morphological changes based on the conformational transition of core-forming peptides have been reported. However, most studies have focused on the switching between assembly and disassembly, triggered by the structural $\alpha$-to-random [14] or $\beta$-to-random transitions [15], which accompanies a sharp change in solubility. On the other hand, significantly less attention has been paid to the 
morphological change that is driven by $\alpha$-to- $\beta$ transition of core-forming hydrophobic polypeptides [2], although such conformational transition can be expected to induce a drastic morphological transition from one morphology to another morphology. Definite conformation of the building blocks both before and after the transformation allows us to precisely design their nanoassemblies. Therefore, the nanostructures that can transform accompanying $\alpha$-to- $\beta$ transition of core-forming peptides can open new opportunities for the applications of smart nanomaterials.

In nature, some proteins often change their aggregation state, which is accompanied by their conformation transition. For example, the process of amyloid fibril formation would be involved in $\alpha-\beta$ conformational transformation of the native proteins, resulting in a high content of beta-sheet structures [16]. Some amyloidogenic proteins have specific core sequences of several amino acid residues within the protein, which often contain aromatic amino acids and are originally prone to adopt $\beta$-sheet conformation $[17,18]$. It is believed that the whole $\alpha-\beta$ conformational transition of amyloidogenic proteins is triggered by the local transition of the core region $[19,20]$. Mimicking this characteristic, we designed triblock conjugates as model molecules, which are composed of oligo(ethylene glycol), oligo(L-lysine), and tetra(L-phenylalanine), for the construction of the smart nanomaterials possessing transformation ability thorough $\alpha-\beta$ conformational transition. Phenylalanine-based aromatic peptides have been widely used as a self-assembling motif for the construction of $\beta$-sheet assemblies, since the aromatic stacking interactions may play an important role for molecular assembly that leads to the formation of amyloid-like nanofibers [21-25]. Therefore, the introduction of tetra(L-phenylalanine) would affect the secondary structure of the peptide segments. Oligo(L-lysine) normally exhibits a random-helix transition in response to the $\mathrm{pH}$ environment at room temperature [26].

Herein, we report a morphological transformation of the core-shell nanostructures composed of the triblock PEG-peptide amphiphiles thorough secondary structure transition of core-forming peptides. The triblock PEG-peptide amphiphiles exhibited different secondary structures that are dependent on the solvent-environment. When peptide segments adopt $\alpha$-helix, the triblock conjugates formed vesicle structures. In addition, the $\alpha-\beta$ transition of the core-forming peptides induced by changing the solvent-environment resulted in morphological transition from vesicles to arc-shaped nanostructures.

\section{Materials and Methods}

\subsection{Materials}

39-amino- $N$-(9-fluorenylmethoxycarbonyl)-4,7,10,13,16,19,22,25,28,31,34,37-

dodecaoxanonatriacontanoic acid (Fmoc- $N$-amido-dPEG 12 acid) was purchased from Quanta BioDesign Ltd. (Plain City, OH, USA). 2-chlorotrityl resin, $N, N$-diisopropylethylamine (DIPEA), $N-\alpha-$ (9-Fluorenylmethoxycarbonyl)- $N$ - $\varepsilon$-(tert-butoxycarbonyl)-L-lysine (Fmoc-Lys(Boc)-OH), $\quad N-\alpha-(9-$ Fluorenylmethoxycarbonyl)-L-phenylalanine (Fmoc-Phe-OH), 1-[bis(dimethylamino)methylene]- $1 \mathrm{H}$ benzotriazolium 3-oxide hexafluorophosphate (HBTU), 1-hydroxybenzotriazole (HOBT), and piperidine were purchased from Watanabe Chemical Industries Ltd. (Hiroshima, Japan). $\mathrm{N}, \mathrm{N}$-dimethylformamide (DMF), isopropanol, methanol, diethyl ether, hexafluoroisopropanol (HFIP), dichloromethane $\left(\mathrm{CH}_{2} \mathrm{Cl}_{2}\right)$, and trifluoroacetic acid (TFA) were purchased from Wako Pure Chemical Industries, Ltd. (Osaka, Japan). 2,2,2-trifluoroethanol (TFE) was purchased from Nacalai Tesque Inc. (Kyoto, Japan).

\subsection{Synthesis of PEG-Peptide Amphiphiles}

Loading of resin: Fmoc- $N$-amido- $\mathrm{dPEG}_{12}$ was dehydrated by an azeotrope with benzene prior to use. A solution of Fmoc- $N$-amido-dPEG 12 acid $(0.238 \mathrm{mmol})$ and DIPEA $(0.952 \mathrm{mmol})$ in $\mathrm{CH}_{2} \mathrm{Cl}_{2}$ $(2.6 \mathrm{~mL})$ was reacted with 2-chlorotrityl resin $(0.397 \mathrm{mmol}, 1.5 \mathrm{mmol} / \mathrm{g}$ loading max $)$ for $12 \mathrm{~h}$.

Peptide synthesis: Coupling reactions were conducted using standard Fmoc protocol. The coupling cycle included Fmoc deprotection ( $20 \%$ piperidine in DMF, 5 min, repeated three times), 
DMF wash, amino acid coupling: L-Fmoc amino acids (4 eq.), HBTU (3.6 eq.), HOBt (4 eq.), and DIPEA (8 eq.) for $30 \mathrm{~min}$ repeated twice, and DMF washed. After all coupling reactions, the obtained peptides were cleaved from the resin by $\mathrm{H}_{2} \mathrm{O} / \mathrm{TFA}$ (5: 95 in volume) for $2 \mathrm{~h}$. Subsequently, the peptide was precipitated in ice cold diethyl ether and filtered, centrifuged, and washed with diethyl ether. The crude peptides were purified by reversed-phase high-performance liquid (RP-HPLC). MS (MALDI-TOF): $\mathrm{K}_{20}-\mathrm{EG}_{12}$; Cald. MASS: 3182.05, Obsd. MASS: 3182.28, $\mathrm{K}_{16} \mathrm{~F}_{4}-\mathrm{EG}_{12}$; Cald. MASS: 3257.90, Obsd. MASS: 3256.10, $\mathrm{F}_{4} \mathrm{~K}_{16}-\mathrm{EG}_{12}$; Cald. MASS: 3257.90, Obsd. MASS: 3256.87.

\subsection{Self-Assembly of PEG-Peptide Amphiphiles in 25 vol \% TFE Aqueous Solution}

To obtain a homogeneous solution of monomeric peptide, the following procedure was used: $\mathrm{F}_{4} \mathrm{~K}_{16}-\mathrm{EG}_{12}$ was dissolved in TFA, sonicated for $5 \mathrm{~min}$, and then dried with nitrogen flow; then, the obtained film was re-dissolved in HFIP, sonicated for $10 \mathrm{~min}$, and dried with nitrogen flow. The HFIP-treated film of $\mathrm{F}_{4} \mathrm{~K}_{16}-\mathrm{EG}_{12}$ was dissolved in TFE at a concentration of $3.7 \mathrm{mM}$. The $750 \mu \mathrm{L}$ $\mathrm{NaHCO}_{3}$ buffer (33 mM, pH 10.7) was added dropwise into a $250 \mu \mathrm{L}$ of TFE solution containing $\mathrm{F}_{4} \mathrm{~K}_{16}-\mathrm{EG}_{12}$ with gentle stirring at the rate of $20 \mu \mathrm{L} / 5 \mathrm{~min}$. The obtained aggregates were analyzed with transmission electron microscopic (TEM), circular dichroic (CD), and dynamic light scattering (DLS). The self-assembly of the other PEG-peptide amphiphiles $\left(\mathrm{K}_{20}-\mathrm{EG}_{12}, \mathrm{~K}_{16} \mathrm{~F}_{4}-\mathrm{EG}_{12}\right)$ was also investigated in a similar manner.

\subsection{Morphological Transition of Vesicles Consisting of PEG-Peptide Amphiphiles by Solvent Exchange}

The dispersion of $\mathrm{F}_{4} \mathrm{~K}_{16}$ - $\mathrm{EG}_{12}$ vesicle in $25 \%$ TFE aqueous solution was dialyzed against $\mathrm{NaHCO}_{3}$ at various $\mathrm{pH}$ values to remove TFE. The resulting nanostructures were observed with TEM and their secondary structures were characterized with CD spectroscopy.

\subsection{Measurements}

\subsubsection{Measurements}

CD measurements were performed on a J-720 spectropolarimeter (JASCO Applied Sciences, Halifax, NS, Canada), with an optical cell of $0.1 \mathrm{~cm}$ optical path length at $25^{\circ} \mathrm{C}$. The HFIP-treated film of the PEG-peptide amphiphiles was dissolved in water or in $25 \mathrm{vol} \%$ TFE aqueous solution at the concentration of $77 \mu \mathrm{M}$. The $\mathrm{pH}$ of the solution was adjusted with $\mathrm{NaOH}$ aq. prior to measurement. The helical content was calculated while using the following equation [27].

$$
\text { Helical content }(\%)=\left(\left[\theta_{208, \text { obs }}\right]-\left[\theta_{208,0}\right] /\left[\theta_{208,100}\right]-\left[\theta_{208,0}\right]\right) \times 100
$$

where $\left[\theta_{208,0}\right]$ is $-4600 \mathrm{deg} \cdot \mathrm{cm}^{2} \cdot \mathrm{dmol}^{-1}$ and $\left[\theta_{208,100}\right]$ is $-33,000 \mathrm{deg} \cdot \mathrm{cm}^{2} \cdot \mathrm{dmol}^{-1}$.

\subsubsection{DLS Analysis}

DLS analysis was performed using a DLS 7000 (Otsuka Electronics Co., Ltd., Osaka, Japan) at $25^{\circ} \mathrm{C}$. The light source was a He-Ne laser $(630 \mathrm{~nm})$ set at an angle of $45^{\circ}$. Experimental data were analyzed using the NNLS algorithm that was provided by the manufacturer.

\subsubsection{TEM Observation}

The samples were negatively stained with $0.1 \%$ phosphotungstate, which was adjusted to $\mathrm{pH} 7.0$ using sodium hydroxide. TEM measurements were performed using a JEM-1200EX II (JEOL, Tokyo, Japan), with an acceleration voltage of $85 \mathrm{keV}$.

\subsubsection{Atomic Force Microscopic (AFM) Observation}

The topologies of the nanostructures consisting of $\mathrm{F}_{4} \mathrm{~K}_{16}-\mathrm{EG}_{12}$ were visualized with a Nanoscope IIIa (Veeco Instruments, Santa Barbara, CA, USA) in tapping mode, and the cantilever was set vibrating 
in the z-direction at a resonance frequency of $290 \mathrm{kHz}$. The images were captured in air under ambient conditions using silicon tips.

\section{Results and Discussion}

Three types of PEG-peptide amphiphiles, $\mathrm{K}_{20}-\mathrm{EG}_{12}, \mathrm{~K}_{16} \mathrm{~F}_{4}-\mathrm{EG}_{12}$, and $\mathrm{F}_{4} \mathrm{~K}_{16}-\mathrm{EG}_{12}$, were synthesized by Fmoc solid phase synthesis, and their secondary structures and self-assembly behaviors were investigated (Table 1). Figure 1 shows the $C D$ spectra of $\mathrm{K}_{20}-\mathrm{EG}_{12}, \mathrm{~K}_{16} \mathrm{~F}_{4}-\mathrm{EG}_{12}$, and $\mathrm{F}_{4} \mathrm{~K}_{16}-\mathrm{EG}_{12}$ at various $\mathrm{pH}$ values in water and in 25\% TFE aq. TFE is a well-known helix-assisted solvent [28]. $\mathrm{CD}$ spectra of $\mathrm{K}_{20}-\mathrm{EG}_{12}$ in water and in $25 \mathrm{vol} \%$ TFE aq. show that the intensity of negative cotton peaks at 222 and $208 \mathrm{~nm}$, which are characteristic of $\alpha$-helix, was increased with increasing $\mathrm{pH}$ through an isodichroic point at around $203 \mathrm{~nm}$ (Figure 1a,b) [27]. These results indicate that $\mathrm{K}_{20}-\mathrm{EG}_{12}$ undergoes a structural transition from random to $\alpha$-helix with increasing $\mathrm{pH}$, both in water and in $25 \% \mathrm{v} / \mathrm{v}$ TFE aq., although the helix content is low in water (Figure S1). In contrast, the transition behavior of $\mathrm{K}_{16} \mathrm{~F}_{4}-\mathrm{EG}_{12}$ and $\mathrm{F}_{4} \mathrm{~K}_{16}-\mathrm{EG}_{12}$ with increasing $\mathrm{pH}$ was quite different depending on the solvent. In the $\mathrm{CD}$ spectra of $\mathrm{K}_{16} \mathrm{~F}_{4}-\mathrm{EG}_{12}$ and $\mathrm{F}_{4} \mathrm{~K}_{16}-\mathrm{EG}_{12}$ in water, the intensity of the negative cotton peaks at 217 $\mathrm{nm}$, characteristic of the $\beta$-sheet [27], was increased with increasing $\mathrm{pH}$, indicating the transition from random to $\beta$-sheet conformation (Figure 1c,e, Figure S2). On the other hand, in 25\% $v / v$ TFE, the intensity of negative cotton peaks at 222 and $208 \mathrm{~nm}$ was increased, indicating the $\mathrm{pH}$-responsive transition from random to $\alpha$-helix conformation (Figure 1d,f). These results clearly indicate that the $\mathrm{F}_{4}$ segment significantly affects the secondary structure of $\mathrm{K}_{16} \mathrm{~F}_{4}-\mathrm{EG}_{12}$ and $\mathrm{F}_{4} \mathrm{~K}_{16}-\mathrm{EG}_{12}$ in basic aqueous solution. The $\mathrm{pH}$ dependences of the helicity for these peptide conjugates in $25 \%$ TFE are shown in Figure S1a. The helicity for all peptides has a maximum value and slightly decreases in the range of higher basic $\mathrm{pH}$, which is possibly due to the low solubility of these peptides under the basic $\mathrm{pH}$ condition. More particularly, the maximum helicity for $\mathrm{K}_{16} \mathrm{~F}_{4}-\mathrm{EG}_{12}$ in $25 \%$ TFE was much smaller than that for $\mathrm{F}_{4} \mathrm{~K}_{16}-\mathrm{EG}_{12}$ and $\mathrm{K}_{20}-\mathrm{EG}_{12}$, indicating that $\mathrm{K}_{16} \mathrm{~F}_{4}-\mathrm{EG}_{12}$ formed some aggregates. These results show that $\mathrm{F}_{4} \mathrm{~K}_{16}-\mathrm{EG}_{12}$ adopts different secondary structures depending on the solvent environment without forming large aggregates; these adopt $\beta$-sheet structures in aqueous solution and $\alpha$-helix structures in $25 \%$ TFE solution under basic $\mathrm{pH}$ condition. Thus, $\mathrm{F}_{4} \mathrm{~K}_{16}-\mathrm{EG}_{12}$ is well suited as a component for the construction of smart nanoassemblies whose transformation is accompanied by a secondary structure transition in response to the solvent environment.

Table 1. Amino acid sequences of the PEG-peptide amphiphiles.

\begin{tabular}{cc}
\hline Abbreviation & Amino Acid Sequence \\
\hline $\mathrm{K}_{20}-\mathrm{EG}_{12}$ & KKKKKKKKKKKKKKKKKKKK-oligo(ethylene glycol) \\
\hline $\mathrm{K}_{16} \mathrm{~F}_{4}-\mathrm{EG}_{12}$ & KKKKKKKKKKKKKKKKFFFF-oligo(ethylene glycol) \\
\hline $\mathrm{F}_{4} \mathrm{~K}_{16}-\mathrm{EG}_{12}$ & FFFFKKKKKKKKKKKKKKKK-oligo(ethylene glycol) \\
\hline
\end{tabular}

Next, we investigate the self-assembly of $\mathrm{F}_{4} \mathrm{~K}_{16}-\mathrm{EG}_{12}$ in $25 \%$ TFE. A basic buffer solution was added dropwise to the TFE solution containing $\mathrm{F}_{4} \mathrm{~K}_{16}-\mathrm{EG}_{12}$ peptide amphiphiles at the rate of $10 \mu \mathrm{L} / \mathrm{min}$ under gentle agitation until the concentration of TFE was $25 \%$. The final concentration of the peptide was $3 \mathrm{mg} / \mathrm{mL}$ and the final $\mathrm{pH}$ value was 9.6. Under basic conditions, the peptide segments of $\mathrm{F}_{4} \mathrm{~K}_{16}-\mathrm{EG}_{12}$ are hydrophobic, because the side amino groups of Lys residues are deprotonated. Thus, the addition of basic water would facilitate the self-assembly of $\mathrm{F}_{4} \mathrm{~K}_{16}-\mathrm{EG}_{12}$ due to their amphiphilic molecular structures composing hydrophobic peptides and hydrophilic oligo (ethylene glycol)). The morphologies of obtained nanostructures were observed by TEM via drop deposition of the sample on $\mathrm{Cu}$ grid and staining with phosphotungstic acid. To prevent the structural change of the nanostructures during sample preparation for TEM observation, the staining reagent was dropped on the grid and then blotted immediately with filter paper. TEM images show that $F_{4} \mathrm{~K}_{16}-\mathrm{EG}_{12}$ formed nanostructures where a contrast between the dark periphery and the lighter center of 
spherical structures was observed, indicating that $\mathrm{F}_{4} \mathrm{~K}_{16}-\mathrm{EG}_{12}$ formed vesicle like structures (Figure 2a, Figure S3a). The DLS measurement of the dispersion shows a monodisperse peak with an average diameter of $268.8 \pm 72.2 \mathrm{~nm}$ (Figure S4a). The DLS date clearly indicates that the nanostructures were indeed formed in solutions. AFM observation revealed that the height of the nanostructures was much lower than the diameter of nanostructures that were estimated from DLS, indicating that nanostructures have hollow structures (Figure S5). In addition, it was confirmed that these nanostructures were stable at least for three days in $25 \%$ TFE solution.
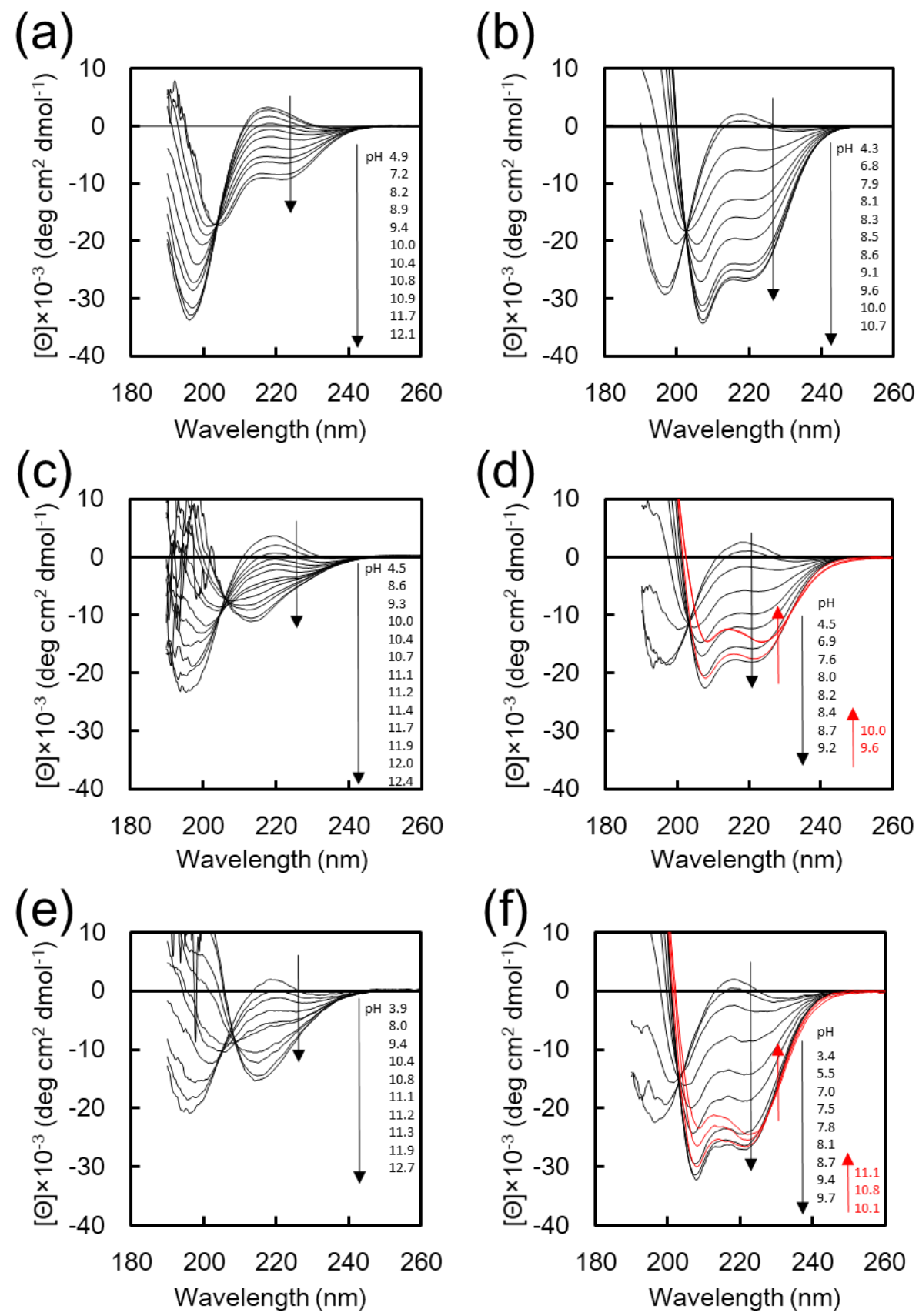

Figure 1. Circular dichroic (CD) spectra of $\mathrm{K}_{20}-\mathrm{EG}_{12}(\mathbf{a}, \mathbf{b}), \mathrm{K}_{16} \mathrm{~F}_{4}-\mathrm{EG}_{12}(\mathbf{c}, \mathbf{d})$, and $\mathrm{F}_{4} \mathrm{~K}_{16}-\mathrm{EG}_{12}(\mathbf{e}, \mathbf{f})$. The measurements were performed in water $(\mathbf{a}, \mathbf{c}, \mathbf{e})$ and in $25 \%$ 2,2,2-trifluoroethanol (TFE) aqueous solution $(\mathbf{b}, \mathbf{d}, \mathbf{f})$ at various $\mathrm{pHs}$ at room temperature. 

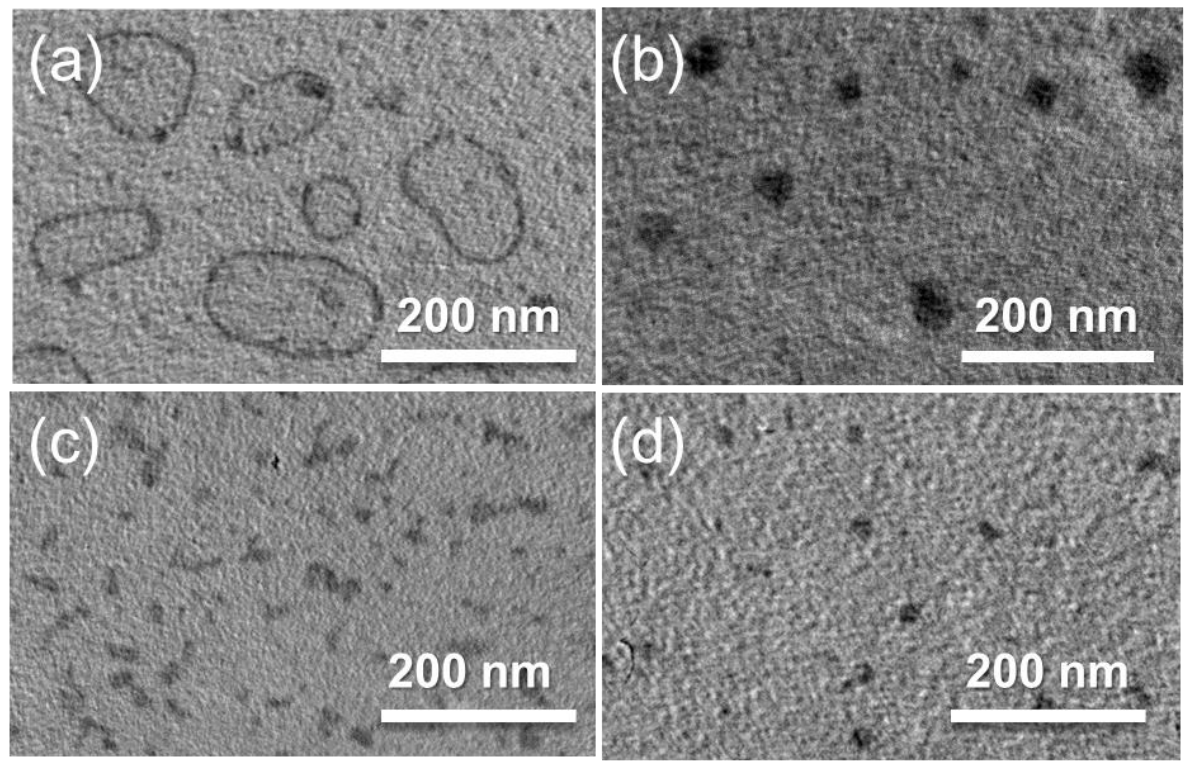

(e)

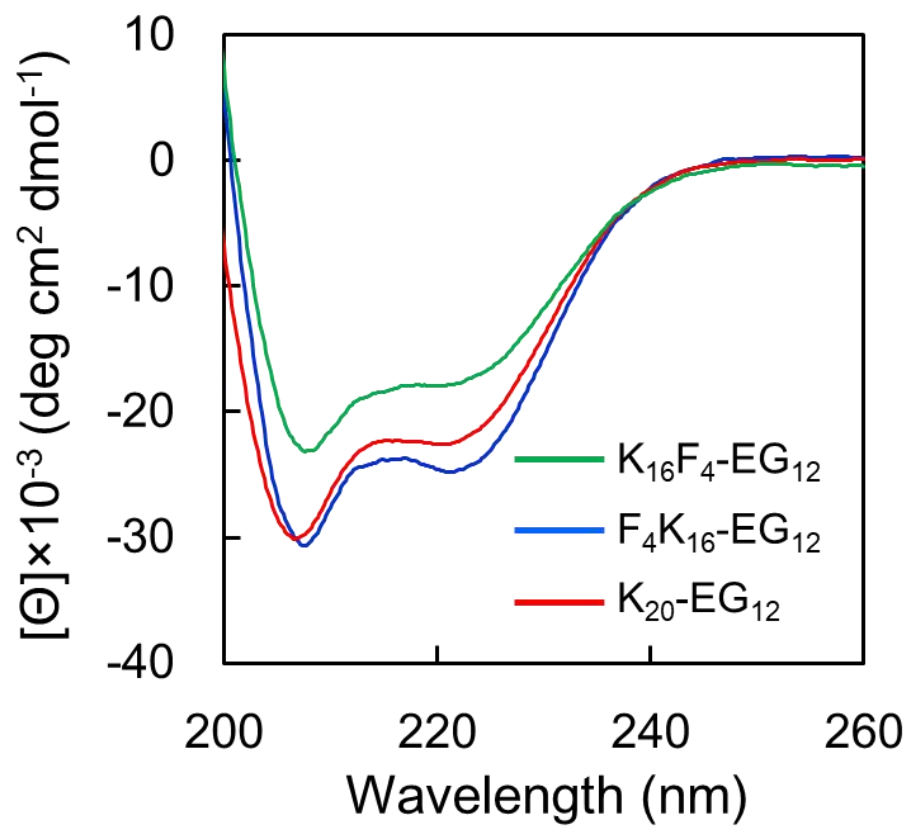

Figure 2. (a,b) Transmission electron microscopic (TEM) images of the nanostructures of $\mathrm{F}_{4} \mathrm{~K}_{16}-\mathrm{EG}_{12}$ obtained in $25 \%$ TFE aqueous solution at $\mathrm{pH} 9.6$ (a) and at $\mathrm{pH} 8.9$ (b). (c) TEM image of the nanostructures of $\mathrm{K}_{20}-\mathrm{EG}_{12}$ obtained in $25 \%$ TFE aqueous solution at $\mathrm{pH}$ 9.3. (d) TEM image of the nanostructures of $\mathrm{K}_{16} \mathrm{~F}_{4}-\mathrm{EG}_{12}$ obtained in $25 \%$ TFE aqueous solution at $\mathrm{pH}$ 9.7. (e) $\mathrm{CD}$ spectra of the nanostructures corresponding to (a) (blue), (c) (red), and (d) (green).

The self-assembly of $\mathrm{F}_{4} \mathrm{~K}_{16}-\mathrm{EG}_{12}$ in $25 \%$ TFE was further studied at various $\mathrm{pH}$ values. More importantly, vesicle formation successfully occurred at a narrow $\mathrm{pH}$ range (9.2-9.7) (Figure S6). At lower $\mathrm{pH}(8.9)$, large compound micelles with a diameter of $40 \pm 8 \mathrm{~nm}$ were observed in preference to vesicles (Figure $2 \mathrm{~b}$, Figures $\mathrm{S} 2 \mathrm{~b}, \mathrm{~S} 4 \mathrm{~b}$ ). The reason why vesicle formation is unlikely to occur in the lower $\mathrm{pH}$ range would be the low helical content of $\mathrm{F}_{4} \mathrm{~K}_{16}-\mathrm{EG}_{12}$. This is consistent with the general consideration that side-by-side interactions of $\alpha$-helical peptides between peptide-bond dipoles may induce vesicle formations [5,29].

The self-assembly of $\mathrm{K}_{20}-\mathrm{EG}_{12}$ or $\mathrm{K}_{4} \mathrm{~F}_{16}-\mathrm{EG}_{12}$ was also evaluated in a similar manner as a control. The TEM image shows that $\mathrm{K}_{20}-\mathrm{EG}_{12}$ formed typical core-corona type micelles with a diameter of 
$10 \pm 4 \mathrm{~nm}$ (Figure 2c, Figure S3c). Although both $\mathrm{K}_{20}-\mathrm{EG}_{12}$ and $\mathrm{F}_{4} \mathrm{~K}_{16}-\mathrm{EG}_{12}$ adopt helical structures with helix content of over $90 \%$, as estimated from CD spectra (Figure 2e), they provided nanostructures with different morphologies. These results suggest that hydrophobicity of tetra(phenylalanine) is significant to form vesicle structures. In addition, $\mathrm{K}_{16} \mathrm{~F}_{4}-\mathrm{EG}_{12}$ forms core-corona type micelles with a diameter of $16 \pm 5 \mathrm{~nm}$, in addition to ill-regulated aggregates (Figure 2d, Figure S3d), indicating that the position of tetra(phenylalanine) is also significant for the formation of vesicle structures.

It is expected that $\mathrm{F}_{4} \mathrm{~K}_{16}-\mathrm{EG}_{12}$ vesicle structures will exhibit morphological transformation with the $\alpha-\beta$ transition of core-forming peptides when the solvent-environment was exchanged from $25 \%$ TFE aq. to water under basic condition, since there is a clear difference in molecular dimension between $\alpha$-helix and $\beta$-sheet conformation. To change the solvent-environment of $\mathrm{F}_{4} \mathrm{~K}_{16}$ - $\mathrm{EG}_{12}$ vesicle, TFE was removed by the dialysis of $\mathrm{F}_{4} \mathrm{~K}_{16}-\mathrm{EG}_{12}$ vesicle dispersion against basic buffer. Interestingly, when vesicle dispersion was dialyzed against carbonate buffer at $\mathrm{pH} 12$, vesicle structures transformed to arc-shaped nanostructures (Figure 3a, Figure S7a). The arc-shaped nanostructures had relatively monodispersed size, in the range of 50-100 nm (Figure S8). AFM observation revealed that the height of arc-shaped nanostructures was about 5-8 $\mathrm{nm}$ (Figure S9). The transformation of the vesicle structures with solvent exchange was significantly affected by the $\mathrm{pH}$ of the buffer used for dialysis. The vesicle-to-arc transformation occurred by dialysis in the $\mathrm{pH}$ range of 11.7-12.3 (path A) (Figure S10). On the other hand, when dialysis was performed in a more acidic $\mathrm{pH}$, ranging from 10.9 to 11.4 (path $\mathrm{B}$ ), long nanofibers were formed (Figure 3b, Figure S7b). Dialysis below $\mathrm{pH} 10.9$ or above $\mathrm{pH} 12.3$ gave irregular aggregates (Figure S11).

To gain insight into the secondary structure of the nanostructures that were obtained after solvent-exchange by dialysis at various $\mathrm{pH}$ values from $\mathrm{F}_{4} \mathrm{~K}_{16}-\mathrm{EG}_{12}$ vesicles, $\mathrm{CD}$ measurements were performed. The transition from $\alpha$-helix to $\beta$-sheet conformation for all samples after dialysis was confirmed (Figure 3c). Based on these CD spectra, the peak intensity at $217 \mathrm{~nm}$, representing to $\beta$-sheet conformation, was plotted as a function of $\mathrm{pH}$ in Figure $3 \mathrm{~d}$. This plot indicates that the $\beta$-sheet content notably increased in the $\mathrm{pH}$ range of 10.1-11.7, reached a maximum value, and decreased above $\mathrm{pH}$ 12.3. More importantly, the $\mathrm{pH}$ region of $10.9-11.4$, where the $\beta$-sheet and random conformation are mixed, is consistent with that where long nanofibers were formed in morphological transition. On the other hand, the formation of arc-shaped nanostructures is observed in the $\mathrm{pH}$ region of 11.7-12.3, where the $\beta$-sheet content reaches saturation.

Based on these results, we propose the mechanism behind vesicle-to-nanofiber and vesicle-to-arc transition, as follows (Figure 3e): Since the increase in $\beta$-sheet content of $\mathrm{F}_{4} \mathrm{~K}_{16}-\mathrm{EG}_{12}$ with increasing $\mathrm{pH}$ is ascribed to the deprotonation of amino groups of Lys residues, it is reasonable to consider that the molecular mobility of $\mathrm{F}_{4} \mathrm{~K}_{16}-\mathrm{EG}_{12}$ in water depends on its $\beta$-sheet content. Long nanofibers were formed by solvent exchanging in the $\mathrm{pH}$ region of 10.9-11.4 (path B). $\mathrm{CD}$ measurements revealed that the secondary structures of $\mathrm{F}_{4} \mathrm{~K}_{16}-\mathrm{EG}_{12}$ were the mixture of random and $\beta$-sheet conformation in this $\mathrm{pH}$ region, indicating that amino groups of Lys residue would be assumed to be partially protonated. This moderate charge would allow the building block peptides to dissociate relatively easily from vesicle and to re-assemble into nanofibers accompanied by the transition into $\beta$-sheet conformation. This speculation is not inconsistent with the results that long nanofibers were formed by simply adjusting the $\mathrm{pH}$ of $\mathrm{F}_{4} \mathrm{~K}_{16}-\mathrm{EG}_{12}$ aqueous solution to 10.9 (Figure S12a). On the other hand, the morphological change of the vesicle into an arc-shaped nanostructure was induced by dialysis in the $\mathrm{pH}$ region of 11.7-12.3 (path A), where the secondary structures of $\mathrm{F}_{4} \mathrm{~K}_{16}-\mathrm{EG}_{12}$ are $\beta$-sheet rich conformation. In this $\mathrm{pH}$ region, the mobility of the building block peptides consisting of vesicles would be low, because amino groups of Lys residue would be deprotonated [30,31]. Therefore, through path $B, \alpha-\beta$ conformational transition of the building block peptides induced by solvent exchange would cause a shift in the type of hydrogen bonding-from intramolecular to intermolecular, i.e., between adjacent molecules. This would induce distortion in the vesicle, resulting in the collapse of vesicles and transformation to arc-shaped nanostructures. This postulated mechanism agrees with the results that $\mathrm{pH}$ adjustment of the $\mathrm{F}_{4} \mathrm{~K}_{16}-\mathrm{EG}_{12}$ solution provided no arc-shaped nanostructures (Figure S12b). 

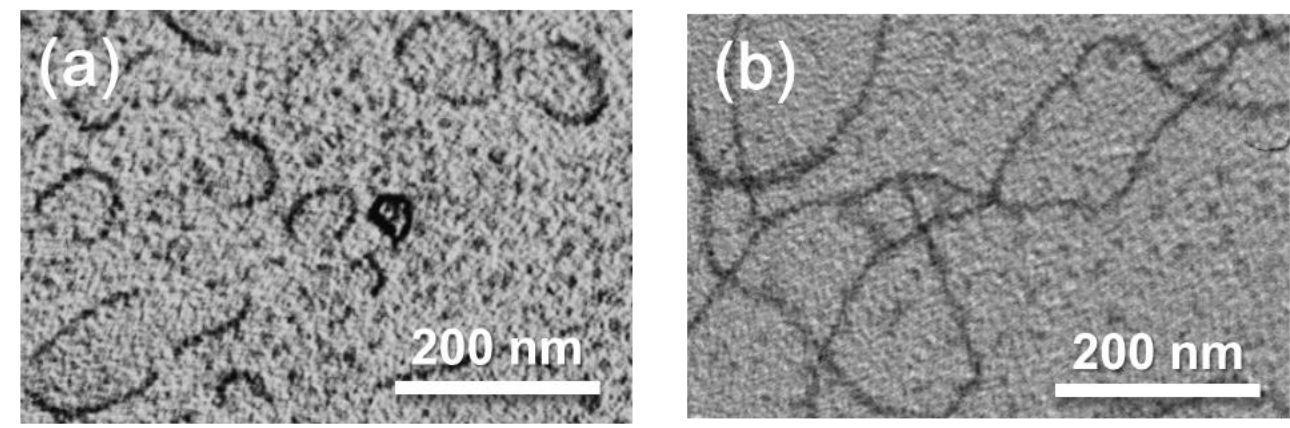

(c)

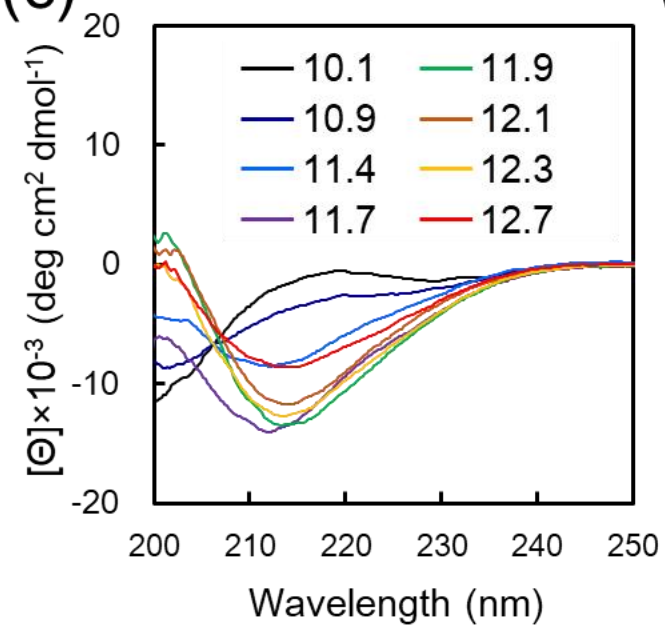

(e)

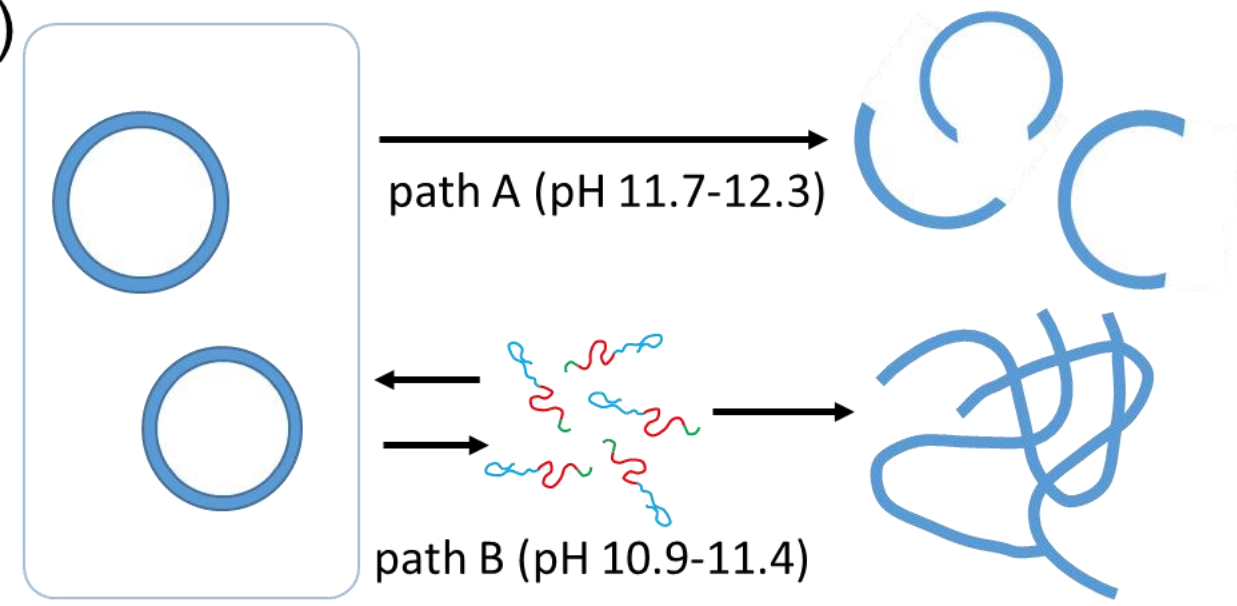

(d)

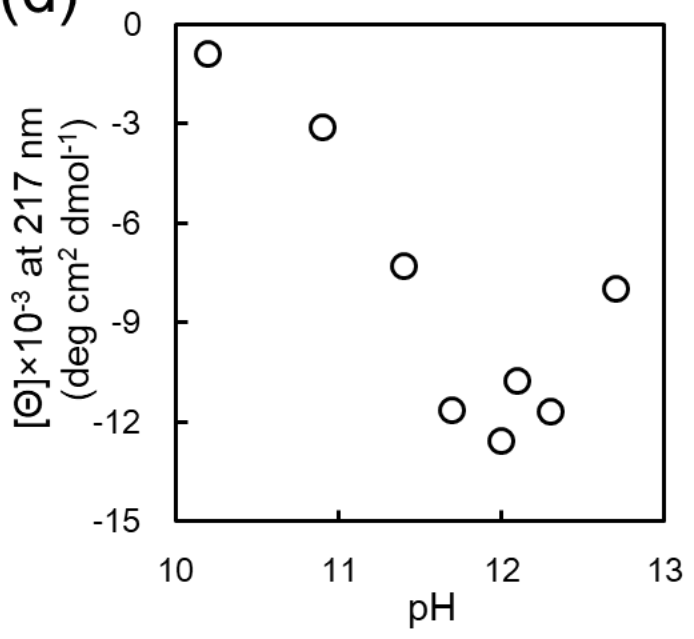

Figure 3. (a,b) TEM images of the nanostructures of $\mathrm{F}_{4} \mathrm{~K}_{16}-\mathrm{EG}_{12}$ obtained by the dialysis of its vesicle dispersion against buffer solution at $\mathrm{pH} 12.0$ (a) and at $\mathrm{pH} 10.9$ (b). (c) $\mathrm{CD}$ spectra of $\mathrm{F}_{4} \mathrm{~K}_{16}-\mathrm{EG}_{12}$ nanostructures obtained by solvent exchange at various pHs. (d) $\mathrm{pH}$ dependence of $\theta_{217}$ for the $\mathrm{F}_{4} \mathrm{~K}_{16}-\mathrm{EG}_{12}$ nanostructures. (e) Schematic illustration of morphological transition of $\mathrm{F}_{4} \mathrm{~K}_{16}-\mathrm{EG}_{12}$ from vesicles to arc-shaped nanostructures or long nanofibers.

\section{Conclusions}

We demonstrated the morphological transition of triblock PEG-peptide amphiphiles containing $\beta$-sheet forming an aromatic sequence from vesicles to arc-shaped nanostructures accompanied by $\alpha-\beta$ transition of core-forming peptides. The triblock PEG-peptide amphiphiles adopted an $\alpha$-helix in $25 \%$ TFE aq., while $\beta$-sheet structures in water under basic $\mathrm{pH}$ condition. TEM observation revealed that the triblock amphiphiles formed vesicle structures in $25 \%$ TFE aq. When the solvent of vesicle dispersion 
was exchanged by dialysis against basic water, the vesicles were transformed into arc-shaped nanostructures with $\alpha-\beta$ conformational transition. We believe that the transformable nanostructures consisting of a building block with definite conformation both before and after transformation may be useful as a novel smart nanomaterial. Further characterization and functionalization of these vesicles consisting of triblock PEG-peptide amphiphiles is currently in progress.

Supplementary Materials: The following are available online at http:/ /www.mdpi.com/2073-4360/11/1/39/s1. Author Contributions: T.W. conceived and designed the experiments; N.H., M.N. and K.N. performed the experiments; All members discussed the experimental data; T.W. wrote the paper.

Acknowledgments: This work was partly supported by the Japan Society for the Promotion of Science (JSPS) KAKENHI Grant number 16K01391.

Conflicts of Interest: The authors declare no conflict of interest.

\section{References}

1. Förster, S.; Antonietti, M. Amphiphilic block copolymers in structure-controlled nanomaterial hybrids. Adv. Mater. 1998, 10, 195-217. [CrossRef]

2. Li, M.H.; Keller, P. Stimuli-responsive polymer vesicles. Soft Matter 2009, 5, 927-937. [CrossRef]

3. Randolph, L.M.; Chien, M.P.; Gianneschi, N.C. Biological stimuli and biomolecules in the assembly and manipulation of nanoscale polymeric particles. Chem. Sci. 2012, 3, 1363-1380. [CrossRef] [PubMed]

4. Fuks, G.; Talom, R.M.; Gauffre, F. Biohybrid block copolymers: Towards functional micelles and vesicles. Chem. Soc. Rev. 2011, 40, 2475-2493. [CrossRef] [PubMed]

5. Tian, B.; Tao, X.; Ren, T.; Weng, Y.; Lin, X.; Zhang, Y.; Tang, X. Polypeptide-based vesicles: Formation, properties and application for drug delivery. J. Mater. Chem. 2012, 22, 17404-17414. [CrossRef]

6. Carlsen, A.; Lecommandoux, S. Self-assembly of polypeptide-based block copolymer amphiphiles. Curr. Opin. Colloid Interface Sci. 2009, 14, 329-339. [CrossRef]

7. Cai, C.; Wang, L.; Lin, J. Self-assembly of polypeptide-based copolymers into diverse aggregates. Chem. Commun. 2011, 47, 11189-11203. [CrossRef]

8. Hamley, I.W. PEG-peptide conjugates. Biomacromolecules 2014, 15, 1543-1559. [CrossRef]

9. Orts Gil, G.; Łosik, M.; Schlaad, H.; Drechsler, M.; Hellweg, T. Properties of pH-responsive mixed aggregates of polystyrene-block-poly(L-lysine) and nonionic surfactant in solution and adsorbed at a solid surface. Langmuir 2008, 24, 12823-12828. [CrossRef]

10. Chécot, F.; Rodriguez-Hernandez, J.; Gnanou, Y.; Lecommandoux, S. pH-responsive micelles and vesicles nanocapsules based on polypeptide diblock copolymers. Biomol. Eng. 2007, 24, 81-85. [CrossRef]

11. Iatrou, H.; Frielinghaus, H.; Hanski, S.; Ferderigos, N.; Ruokolainen, J.; Ikkala, O.; Richter, D.; Mays, J.; Hadjichristidis, N. Architecturally induced multiresponsive vesicles from well-defined polypeptides. Formation of gene vehicles. Biomacromolecules 2007, 8, 2173-2181. [CrossRef] [PubMed]

12. Chécot, F.; Lecommandoux, S.; Gnanou, Y.; Klok, H.A. Water-soluble stimuli-responsive vesicles from peptide-based diblock copolymers. Angew. Chem. Int. Ed. 2002, 41, 1339-1343. [CrossRef]

13. Kukula, H.; Schlaad, H.; Antonietti, M.; Förster, S. The formation of polymer vesicles or "peptosomes" by polybutadiene-block-poly(L-glutamate) $\mathrm{s}$ in dilute aqueous solution. J. Am. Chem. Soc. 2002, 124, 1658-1663. [CrossRef] [PubMed]

14. Bellomo, E.G.; Wyrsta, M.D.; Pakstis, L.; Pochan, D.J.; Deming, T.J. Stimuli-responsive polypeptide vesicles by conformation-specific assembly. Nat. Mater. 2004, 3, 244-248. [CrossRef] [PubMed]

15. Kühnle, R.I.; Börner, H.G. Calcium ions to remotely control the reversible switching of secondary and quaternary structures in bioconjugates. Angew. Chem. Int. Ed. 2011, 50, 4499-4502. [CrossRef] [PubMed]

16. Kirkitadze, M.D.; Condron, M.M.; Teplow, D.B. Identification and characterization of key kinetic intermediates in amyloid beta-protein fibrillogenesis. J. Mol. Biol. 2001, 312, 1103-1119. [CrossRef] [PubMed]

17. Balbach, J.J.; Ishii, Y.; Antzutkin, O.N.; Leapman, R.D.; Rizzo, N.W.; Dyda, F.; Reed, J.; Tycko, R. Amyloid fibril formation by A $\beta 16-22$, a seven-residue fragment of the Alzheimer's $\beta$-amyloid peptide and structural characterization by solid state NMR. Biochemistry 2000, 39, 13748-13759. [CrossRef]

18. Nelson, R.; Sawaya, M.R.; Balbirnie, M.; Madsen, A.Ø.; Riekel, C.; Grothe, R.; Eisenberg, D. Structure of the cross- $\beta$ spine of amyloid-like fibrils. Nature 2005, 435, 773-778. [CrossRef] 
19. Tanaka, N.; Morimoto, Y.; Noguchi, Y.; Tada, T.; Waku, T.; Kunugi, S.; Morii, T.; Lee, Y.-F.; Konno, T.; Takahashi, N. The mechanism of fibril formation of a non-inhibitory serpin ovalbumin revealed by the identification of amyloidogenic core regions. J. Biol. Chem. 2011, 286, 5884-5894. [CrossRef]

20. Yamaguchi, K.; Katou, H.; Hoshino, M.; Hasegawa, K.; Naiki, H.; Goto, Y. Core and heterogeneity of beta2-microglobulin amyloid fibrils as revealed by H/D exchange. J. Mol. Biol. 2004, 338, 559-571. [CrossRef]

21. Mayans, E.; Ballano, G.; Casanovas, J.; Díaz, A.; Pérez-Madrigal, M.M.; Estrany, F.; Puiggali, J.; Cativiela, C.; Alemán, C. Self-assembly of tetraphenylalanine peptides. Chem. Eur. J. 2015, 21, 16895-16905. [CrossRef] [PubMed]

22. Fleming, S.; Ulijn, R.V. Design of nanostructures based on aromatic peptide amphiphiles. Chem. Soc. Rev. 2014, 43, 8150-8177. [CrossRef] [PubMed]

23. Reches, M.; Gazit, E. Casting metal nanowires within discrete self-assembled peptide nanotubes. Science 2003, 300, 625-627. [CrossRef]

24. Tzokova, N.; Fernyhough, C.M.; Topham, P.D.; Sandon, N.; Adams, D.J.; Butler, M.F.; Armes, S.P.; Ryan, A.J. Soft hydrogels from nanotubes of poly (ethylene oxide)-tetraphenylalanine conjugates prepared by click chemistry. Langmuir 2009, 25, 2479-2485. [CrossRef] [PubMed]

25. Castelletto, V.; Hamley, I.W. Self-assembly of a model amphiphilic phenylalanine peptide/polyethylene glycol block copolymer in aqueous solution. Biophys. Chem. 2009, 141, 169-174. [CrossRef] [PubMed]

26. Harada, A.; Cammas, S.; Kataoka, K. Stabilized $\alpha$-helix structure of poly(L-lysine)-block-poly (ethylene glycol) in aqueous medium through supramolecular assembly. Macromolecules 1996, 29, 6183-6188. [CrossRef]

27. Greenfield, N.J.; Fasman, G.D. Computed circular dichroism spectra for the evaluation of protein conformation. Biochemistry 1969, 8, 4108-4116. [CrossRef]

28. Hirota, N.; Mizuno, K.; Goto, Y. Cooperative $\alpha$-helix formation of $\beta$-lactoglobulin and melittin induced by hexafluoroisopropanol. Protein Sci. 1997, 6, 416-421. [CrossRef]

29. Schatz, C.; Louguet, S.; Le Meins, J.F.; Lecommandoux, S. Polysaccharide-block-polypeptide copolymer vesicles: Towards synthetic viral capsids. Angew. Chem. Int. Ed. 2009, 48, 2572-2575. [CrossRef]

30. Koga, T.; Taguchi, K.; Kobuke, Y.; Kinoshita, T.; Higuchi, M. Structural regulation of a peptide-conjugated graft copolymer: A simple model for amyloid formation. Chem. Eur. J. 2003, 9, 1146-1156. [CrossRef]

31. Koga, T.; Higuchi, M.; Kinoshita, T.; Higashi, N. Controlled self-assembly of amphiphilic oligopeptides into shape-specific nanoarchitectures. Chem. Eur. J. 2006, 12, 1360-1367. [CrossRef] [PubMed] 